\title{
ós Modernidade: que tempos são estes?
}

\section{Adriano D. Quadrado 1}

\begin{abstract}
Resumo: O artigo estuda a teoria acerca da pós-modernidade e visita alguns dos principais autores que escreveram sobre o tema. Partindo da oposição do período atual com o período moderno, o estudo entende que vivemos tempos paradoxais, tempos de aparente ruptura, que se definem como a negação do que antes havia, mas que também conservam características da era anterior. $\mathrm{O}$ artigo discute a idéia de que hoje não temos mais modelos e discursos que sirvam a todos, mas a busca solitária de indivíduos em um mundo que se define pela funcionalidade e pelo consumo. Por fim, o estudo tenta entender como se sente este indivíduo pósmoderno, seus desafios e contradiçōes.
\end{abstract}

Palavras-chave: pós-modernidade, identidade, filosofia.

\begin{abstract}
The article studies the theory on postmodernism and visits some of the main authors that wrote on this subject. Starting by the opposition between the current period and the modern period, the study understands that we are living paradoxical times, times of apparent rupture, that define themselves through the denial of what there had been before, but that also preserve characteristics of the previous era. The article discusses the idea that nowadays we no longer have models and ideologies that suit everyone, but the lonely quest of individuals in a world that is defined by functionality and consume. Finally, the study tries to understand the feelings of the postmodern individual, his challenges and contradictions.
\end{abstract}

\section{Key words: postmodernity, identity, philosophy.}

1 Adriano Davanço Quadrado é jornalista e mestre em comunicação social pela ECA-USP, tendo apresentado a dissertação Inferno pós-moderno: marcas da contemporaneidade em Hotel Hell e outras obras da Geração 90, que estuda os textos da nova geração de prosadores brasileiros. O trabalho está disponível na íntegra em formato PDF no endereço

http://www.quadrado.com/MESTRAD

O Adriano Quadrado.pdf
Que tempos são estes em que vivemos? Por falta de nome melhor ou por força do hábito, referimo-nos a eles como tempos pós-modernos, mas a verdade é que nem consenso há sobre a existência de uma pós-modernidade $\mathbf{2}$. Para alguns, mesmo adentrando o novo milênio, seguimos modernos, tão modernos quanto os da Semana de Arte de 1922, para ilustrarmos com um exemplo extremo. Ou menos do que isso, como julga Jürgen Habermas, para quem a pósmodernidade é um retrocesso, um ataque de forças neoconservadoras contra os 
Este texto apresentará os termos "pós-modernidade" e "pósmodernismo" como sinônimos, apesar de entender que o último se refere especificamente às manifestações culturais do atual momento histórico e o primeiro a este período de maneira geral. Preferencialmente usará o primeiro.

ideais do Iluminismo. Outros, porém, dizem que a pós-modernidade é para o homem período histórico especial, momento em que se abrem oportunidades de transformações jamais vistas, quando tudo muda velozmente e surgem chances inéditas de saltos evolutivos. Alguns chegam a ver o período em que vivemos como a era em que tudo mudou, quando a história teve seu fim decretado e quando agora nada mais pode ser totalizado em um pacote coerente.

A discussão em torno da pós-modernidade, bem ao estilo de nossa época, se faz cheia de contradições. Mais do que isso, as feições da contemporaneidade confundem-se com a própria teoria acerca do pós-moderno. Como bem percebeu Fredric Jameson, o avanço da discussão sobre a pósmodernidade acabou por forjar muito daquilo que hoje entendemos como as características do momento vivido, de modo que não nos é possível saber se discutimos a própria pós-modernidade ou a teoria que criamos sobre ela. Escreve Jameson logo na abertura de seu livro Pós-modernismo: a lógica cultural do capitalismo tardio:

\footnotetext{
De fato, uma das características mais marcantes do pós-moderno é o modo pelo qual, nesse período, inúmeras análises de tendências, até agora de natureza bastante diferente [...] se aglutinaram todas para formar um novo gênero discursivo, a que podemos muito bem denominar "teoria do pós-modernismo", e isso por si só já é um fato digno de nota. Trata-se, claramente, de uma classificação que inclui a si mesma e eu acho muito bom não ter que decidir se os capítulos que se seguem são uma investigação sobre a natureza da "teoria do pós-modernismo" ou apenas exemplos dela. (JAMESON, 1996: 14)
}

Mesmo antes da formação do gênero discursivo, há a história de sucesso do próprio termo pós-modernidade, que, na ironia de Jameson, deveria ser escrita em forma de best-seller. Diz o pensador norte-americano que há muito estávamos precisando, sem saber, de uma palavra como pós-modernismo. Precisávamos de um nome para tentar organizar toda essa experiência contraditória que vimos vivendo nas últimas décadas, pois os termos antes utilizados para nomear nossa época -como pós-estruturalismo ou sociedade pós-industrial- eram por demais restritos para lograr a disseminação do multivalente pós-modernismo/pósmodernidade. Variações sobre o mesmo tom também são facilmente encontradas, entre elas os termos "neomodernidade" (PROENCCA FILHO, 1988:14), "supermodernidade" (KODO, 2001: 50), "modernidade tardia" ou "tardomodernidade" (BARRENTO, 2001: 21). Em todos os casos, porém, é sintomático o fato de não utilizarmos nome próprio, exclusivo para a era em que vivemos, visto que inevitavelmente apenas atrelamos prefixo ou adjetivo à palavra modernidade. Como explica o ensaísta português João Barrento, "o termo (tal como o de 'moda') deriva do latim modo (ablativo de modus), que refere aquilo que é de agora, do instante, recente ou circunstancial" (BARRENTO, 2001: 16) . Ora, como poderíamos nomear algo que veio depois do agora?

Porém assim o sentimos ou desejamos senti-lo: o tempo depois do agora, o momento em que tudo mudou, que portanto só pode ser nomeado em oposição ao que antes havia. Para Linda Hutcheon, entretanto, o pós-moderno "não assinala uma mudança utópica radical" (HUTCHEON, 1991: 16). De acordo com a pesquisadora canadense, a pós-modernidade de forma alguma representa ruptura em relação ao que antes havia. Nossa era, segundo ela, é auto-reflexiva e paródica, irresoluta e contraditória, uma "força problematizadora" que questiona e desafia a cultura a partir da própria cultura, de seu próprio interior, sem entretanto implodi-la (HUTCHEON, 1991: 13). Diz ela: 
[...] o pós-modernismo é um empreendimento fundamentalmente contraditório: ao mesmo tempo, suas formas de arte (e sua teoria) usam e abusam, estabelecem e depois desestabilizam a convenção de maneira paródica, apontando autoconscientemente para os próprios paradoxos e o caráter provisório que a elas são inerentes, e, é claro, para sua reinterpretação crítica ou irônica em relação à arte do passado. (HUTCHEON, 1991: 43)

Seja como for, o nome pós-modernidade é porta aberta a qualquer idéia. Traz a esperança de liberdade inédita, "a promessa de acabar com tudo o que podia ser considerado asfixiante, insatisfatório ou monótono" (JAMESON, 1996: 18) na era anterior à nossa. A discussão sobre a pós-modernidade, como se vê, começa e avança pelo território da linguagem. Estamos vivendo o tempo em que a realidade torna-se a teoria de que dela fazemos, a era da paródia e do simulacro, da virtualidade cibernética, da convivência pacífica de discursos antagônicos, a era em que tudo nos parece possível. Podemos atrelar ao termo qualquer percepção de mundo, podemos encontrar na pós-modernidade a confirmação de ideologias, o veículo de esperanças, a válvula de escape de frustrações, daí a infinidade de leituras possíveis sobre nossos tempos. Abordaremos, a seguir, algumas dessas leituras.

\section{Modernidade X Pós-modernidade}

Interessante é a pós-modernidade. A primeira grande discussão sobre nossa era é se ela de fato existe, isto é, se realmente vivemos novos tempos ou se ainda trilhamos os caminhos da modernidade. Os argumentos daqueles que defendem que nunca houve algo como uma era pós-moderna apóiam-se na idéia de que ainda vivemos o paradigma moderno. Para o pensador francês Gilles Lipovetsky, a sociedade ocidental continua a ser sustentada pelos mesmos valores definidos pelos modernos, aquilo que ele chama de "elementos constitutivos da modernidade", válidos desde o século 18, que formam o tripé de sustentação de nossa cultura:

\footnotetext{
O primeiro [elemento constitutivo] é o indivíduo, isto é, uma sociedade que reconhece os direitos do homem, com seu correlato, que é a democracia. O segundo elemento é o mercado: Adam Smith, a "mão invisível", já no século 18. E o terceiro elemento é a dinâmica tecnocientífica. Esses três elementos constitutivos da modernidade nunca chegaram a ser destruídos. (PERES, 2004: 5)
}

Lipovetsky admite, entretanto, que atualmente vivemos "a radicalização dessas três lógicas", daí lançar mão do termo "hipermodernidade" para nomear os tempos ora experimentados. É fácil perceber que mesmo aqueles que defendem a idéia de que a modernidade ainda não foi superada não deixam de admitir que algo mudou, incluindo a seguir os prefixos e adjetivos cabíveis ao termo ou postulando um novo "ciclo" (PROENÇA FILHO, 1988:14) da mesma e já vetusta era moderna. É interessante notar novamente a presença das contradições pós-modernas na própria teoria sobre a pós-modernidade, mesmo -e sobretudo- em relação àqueles que inicialmente não reconhecem sua existência. $\bigcirc$ teórico literário lhab Hassan defendeu em seus primeiros textos que o pós-moderno seria apenas a evolução do próprio modernismo. Não obstante, desenhou conhecida tabela, que veremos adiante, enumerando absolutas oposições entre esses dois períodos. Outro teórico literário, Steven Connor, comenta a contradição em Hassan: 
[...] um dos problemas mais evidentes para quem tentar extrair da obra de Hassan uma definição do que o pós-modernismo poderia ser é a sua resoluta insistência em que "o espírito pós-moderno está enrodilhado no grande corpo do modernismo" [citando The Dismemberment of Orpheus: Towards a Postmodern Literature]. Isso nos faz ver o pós-modernismo como, em parte, uma espécie de vírus dionisíaco instalado no modernismo, tentando levá-lo aos extremos da insanidade e da autodissolução, e, em parte, como o secreto princípio interior do modernismo. (CONNOR. 1992: 93-94)

O livro de Hassan, publicado pela primeira vez em 1971, ganha posfácio no ano de 1982, trazendo a conhecida tabela de oposiçōes com a qual Hassan avança em sua análise e se permite "ver o pós-modernismo como oposto ao modernismo, e não como reformulação dele" (CONNOR. 1992: 94). Vejamos, no exercício de Hassan, como a teoria da pós-modernidade começa a se fazer na desconstrução do que antes havia. Eis versão resumida da tabela:

Tabela proposta por Hassan (1982)

\begin{tabular}{|c|c|}
\hline Modernismo & Pós-modernismo \\
\hline Forma (conjuntiva, fechada) & Antiforma (disjuntiva, aberta) \\
\hline Propósito & Jogo/brincadeira [play] \\
\hline Desenho & Acaso \\
\hline Hierarquia & Anarquia \\
\hline Síntese & Antítese \\
\hline Centração & Dispersão \\
\hline Seleção & Combinação \\
\hline Narrativa & Antinarrativa \\
\hline Paranóia & Esquizofrenia \\
\hline Determinação & Indeterminação \\
\hline Transcendência & Imanência \\
\hline
\end{tabular}

Antes de continuarmos a averiguar a suposta polaridade entre as duas eras, um parêntese. Lembremos de outra interessante observação feita por Connor no mesmo Cultura pós-moderna. Segundo ele, as teorias da pós-modernidade, antes de desconstruir o modernismo, tiveram primeiro de criar e disseminar toda uma concepção fechada e bastante rígida de modernidade. Para que houvesse o pósmoderno, seria preciso que primeiro tivéssemos o modelo antagonista de modernidade e que ele fosse sólido e bem definido para que pudesse ser identificado e depois demolido. $\bigcirc$ próprio Connor relaciona (p. 90) algumas das características desse modelo moderno manufaturado por nós, daqui da pósmodernidade, no caso em relação à literatura do alto modernismo, incluindo aí a tendência ao subjetivismo, à introspecção e à proposta pouco modesta de engendrar grande arte literária ao longo de densos romances. Abordagem certamente diferente da que encontramos nas típicas peças literárias pós-modernas: apressadas, extrovertidas, despretensiosas e sucintas. Mas Connor nos lembra de que o modernismo não era tão obediente ao modelo que dele criamos. Havia na manifestação cultural da modernidade aspectos do que hoje se rotula de pósmoderno, assim como no século 21 se publicam peças que poderiam ter sido lançadas durante o modernismo. Ainda outro lembrete se faz necessário antes de prosseguirmos. As oposições estanques entre pós-modernidade e modernidade de forma alguma são aceitas unanimemente. Linda Hutcheon discorda das listas de pares de opostos precisamente por considerar o pós-moderno como força de natureza paradoxal e provisória. Como escreve em sua Poética do pós-modernismo:

Grande parte do que foi escrito sobre o assunto assumiu fisicamente a forma de colunas opostas, normalmente intituladas 'modernismo versus pós-modernismo'. Mas essa é uma estrutura que, implicitamente, nega a natureza híbrida, plural e contraditória do empreendimento pós-moderno. (HUTCHEON, 1991: 39). 
Ressalvas feitas -qualquer análise sobre a pós-modernidade será cheia de ressalvas-, somemos à tabela de oposições de Hassan exercício similar feito Barrento em seu livro A espiral vertiginosa:

Tabela proposta por Barrento (2001: 40)

\begin{tabular}{|c|c|}
\hline Modernidade & Pós-modernidade \\
\hline Racionalidade & Crítica da razão/irracionalismo \\
\hline Pensamento de unidade & Pensamento da "diferença" \\
\hline Totalidades sistemáticas & Fragmentação assistemática \\
\hline Estrutura & Desconstrução \\
\hline Sentido ético & Vazio ético \\
\hline Crítica das ideologias & Fim da ideologia \\
\hline Vivência crítica da crise & Convivência acrítica da crise \\
\hline Superstição do "novo" & Reciclagens e revivalismos \\
\hline Arte do profundo e do elementar & Arte do superficial e do acidental \\
\hline
\end{tabular}

Na tabela de Barrento, notamos ligadas à modernidade primeiramente as idéias de razão, unidade, estrutura e sistema, todas elas confrontadas por termos contrários na coluna da direita, a da pós-modernidade: irracionalismo, diferença, fragmentação e desconstrução. Aqui, portanto, o sentimento de que os tempos atuais são a quebra de algo que antes se percebia como unidade, daí outra dificuldade em se encontrar termo próprio para nossa época, já que ela se define negativamente pelo que não é, pelo que deixou de ser. Ainda na mesma tabela, temos a seguir as noções modernas de ética, estética e ideologia contrapostas novamente por suas negações pós-modernas: vazio ético, fim da ideologia e ecletismo estético, este também no sentido de algo não definível em oposição ao que antes se podia nomear. E mais: aquilo que antes cultuava a originalidade foi substituído por adoradores do pastiche intertextual, aquilo que primeiro era alvo de uma ironia que se pretendia séria, hoje no máximo é mote para piada despretensiosa.

A tabela comparativa de Hassan vai pelo mesmo caminho, polarizando forma com antiforma, propósito com brincadeira, hierarquia com anarquia, síntese com antítese, assim temos mais uma vez os prefixos de negação do lado direito da tabela. $O$ que antes era centrado hoje se dispersou, o que inicialmente se determinava agora se indeterminou. Não há mais a busca pela transcendência e o que primeiro projetava sua loucura paranóica na diferença em relação ao outro agora sucumbiu à fragmentação esquizofrênica do eu. Tudo se quebra na pós-modernidade. $\mathrm{O}$ vaso trincou, depois rachou, por fim fragmentou-se em mil pedaços. A pós-modernidade parece decretar que nunca mais teremos algo parecido com uma unidade. Como vimos, mesmo aqueles que julgam a pós-modernidade como apêndice superestimado do modernismo admitem que os tempos de agora nos trazem novidades. Ainda que retrocesso neoconservador, ainda que mera intensificação de aspectos do período anterior, podemos sentir que a pós-modernidade tem ares diversos daqueles que deram alento aos modernos. Mesmo que alguns dos pilares da modernidade sigam firmes, sabemos que a experiência de vida neste começo de milênio é bem diferente do que, voltando ao nosso primeiro exemplo, aquela vivenciada pelos artífices da Semana de 22.

E qual a grande novidade pós-moderna senão esse sentimento de ruptura, desconstrução, descentramento, negação da unidade que antes havia ou supúnhamos haver? A multiplicidade de idéias, julgamentos, pontos de vista, conceitos e modos de viver fazem com que hoje seja muito difícil estruturar modelos sólidos de interpretação da realidade. Certamente o germe disso já estava na modernidade, mas agora os vazamentos estão por toda a casa, as exceções estão em todas as regras. Nossa única certeza é a de que ora não temos 
mais certezas, somente fragmentos e multiplicidade. Por isso, qualquer tentativa radical de totalização da experiência pós-moderna será, de saída, empreitada temerária. $\bigcirc$ exercício de teorização sobre a pós-modernidade já parte do vórtice pós-moderno de idéias e experiências complexas, como observou Jameson. É inglória a missão do teórico da pós-modernidade de esboçar um perfil coerente daquilo que se define pela incoerência, ou melhor, pela multiplicidade de possíveis coerências. $\bigcirc$ próprio Jameson, assim como Habermas, optou pela abordagem marxista dos fenômenos culturais de nossa época, mas o marxismo, ironicamente, foi a grande vítima da iconoclastia pós-moderna. Não por causa de uma diabólica estratégia das forças conservadoras como insistiria o marxista anacrônico, pois nem diabo há mais em que se acredite. Qualquer texto sobre a pós-modernidade desde seu primeiro parágrafo já nasce para ser questionado, criticado, relativizado.

Não será diferente com este que agora se lê, portanto não faremos mais do que tentativas de esboçar algumas feições provisórias do ser pós-moderno, este que se olha no espelho e nem sabe se existe. Pois tal é o sentimento da pósmodernidade: tudo é incerto, tudo é relativo, tudo é provisório. A pósmodernidade aponta para o esgotamento do modelo, que nos vem desde os gregos, da tentativa de apreensão da realidade por meio da razão. Ao mesmo tempo, anuncia o retorno à estaca zero da certeza socrática de que nada sabemos. Quais são os efeitos de se saber que nada se sabe, que tudo é provisório? Primeiramente temos a propalada humildade do pós-moderno em oposição às grandiosas pretensões modernistas, pretensões que agora vemos como fruto da ingenuidade moderna. Tolos nos parecem os modernos, que podiam em sua inocência acreditar no projeto racional de mundo, qualquer que fosse ele, mas os modernos são velhos, ficaram no tempo. $\bigcirc$ alto modernismo de quase cem anos atrás agora nos parece bem pouco "moderno" no sentido vulgar da palavra. $\bigcirc$ contemporâneo sabe que deve ser humilde, qualidade que decorre mais de uma inevitabilidade do que da duvidosa propensão pós-moderna à virtude, já que hoje preferimos o funcional ao ideológico.

Mas ao se livrar da megalomania ingênua da era anterior, a pósmodernidade se abre ao inesperado. Ao deixar de crer cegamente nos ícones do passado, abre espaço para coadjuvantes que passavam desapercebidos. Outro ganho do fim das certezas, da derrocada dos modelos, é a maior chance de obtermos avanços por vias ainda não exploradas -e isso não só nas artes. A "boa notícia", diz Connor ao analisar as observações de Lyotard de que a ciência tornou-se livre de restrições ideológicas, é que podemos dar "saltos nãoortodoxos" no desenvolvimento científico (CONNOR. 1992: 33). Como se sabe, o esgotamento de um modelo primeiramente traz desconforto, mas a seguir abre a possibilidade de salto evolutivo. Sentimos as duas coisas, o desconforto da desconstrução dos modelos e a esperança de recomeço. Se a esperança procede ou se estamos apenas vivendo a esquizofrenia de uma era contraditória, o futuro dirá. Seja como for, as chances de saltos heterodoxos crescem com o avanço da pós-modernidade. Crescem de maneira exponencial, pois os avanços científicos, a cada ano, fazem com que o tempo pareça correr mais depressa. Os intervalos entre as mudanças no cenário ficam cada vez mais curtos.

A "compressão espaço-tempo" (HALL, 2004: 69) é outra das características mais comentadas da pós-modernidade. As distâncias são encurtadas, tudo se dá cada vez mais rápido. Ao redor do mundo, toda uma geração de jovens ultramodernos, gigaeletrônicos, superurbanos se empanturram de informação em quantidades e velocidade jamais imaginadas em nosso passado. A capacidade de remodelar e difundir informações e idéias de maneira descentralizada não pode mais ser contida. Os tempos de hoje -pós-virada de 
milênio, pós-popularização da internet, pós-11 de Setembro- já não são mais os mesmos de dez anos atrás, quando, para ficarmos num único exemplo, a internet comercial ainda era um bebê desajeitado e feioso. Os últimos anos da década de 1950, identificados por Lyotard como marco do início da pós-modernidade, como vão longe! Daí termos um problema a mais para apontar ao teórico pósmoderno. Além de ousar tentar dar forma à era que rejeita enquadramentos, ele verá suas observações tornarem-se obsoletas muito rapidamente. De que pósmodernidade falaremos, daquela dos anos 1970 ou desta de 2006? E qual será o valor de um texto de 2006 daqui a dez anos? O livro-marco de Lyotard sobre o tema, A condição pós-moderna, de 1979, gerou ao longo das últimas décadas críticas de todos os tipos. Talvez a única unanimidade hoje em relação à obra do pensador francês seja o fato de ela ter dado, pela primeira vez, dimensão histórica à pós-modernidade (RAMíREZ, 2004: 72).

A sensação de aceleração do tempo juntamente com a iconoclastia pósmoderna acabam por criar outra faceta reconhecida da nossa era, a da perda da historicidade. A memória de curto alcance dos contemporâneos e a supervalorização da novidade ajudam a provocar a sensação de que estamos vivendo era absolutamente inédita na história humana, a impressão de que somos a geração que teve o privilégio de testemunhar o momento em que tudo mudou. Uma afirmação exagerada na opinião de Stuart Hall:

\footnotetext{
Não quero negar que passamos por profundas mudanças qualitativas entre o que havia antes e o que temos agora. Agora existem, portanto, algumas características espantosas na cultura contemporânea que certamente tendem a ultrapassar os conceitos teóricos e críticos gerados no primeiro período do modernismo [...] Também aceito que essas mudanças podem significar novas posições subjetivas e identidades sociais para as pessoas. Mas não acho que exista algo absolutamente novo e unificado como a condição pós-moderna. Essa é uma outra versão para a característica amnésia histórica da cultura americana - a tirania do Novo. (MORLEY; CHEN, 1996: 133)
}

Aqui Hall repete uma das idéias centrais de sua análise da contemporaneidade, a de que a pós-modernidade é, antes de tudo, fenômeno predominantemente ocidental ou, antes, norte-americano. De acordo com o teórico jamaicano, boa parte do mundo em muitos aspectos ainda nem entrou na modernidade, esta que dizem ter sido varrida pelas ventanias da novidade pós-moderna. Há mudanças significativas, é claro, mas há ideologia também por trás do discurso sobre o tempo das grandes mudanças. Em certa medida, o fenômeno da pós-modernidade foi exportado ideologicamente pela cultura norte-americana, que assim pôde disseminar sua noção de contemporaneidade em escala global. Como diz Hall, a idéia de que vivemos uma espécie de fim dos tempos, a impressão de que "a história acaba conosco e não há lugar para irmos depois disso" (MORLEY; CHEN, 1996: 134) é sinal claro da presença do componente ideológico. Visão semelhante é a de Anthony Giddens, que também acusa a presença de discurso onde outros apontam supostos fatos que comprovariam o fim da história na pós-modernidade. Giddens diz que podemos escrever a história de diversas maneiras, o que não podemos é ancorar o texto histórico em referência a um ponto arquimediano para justificar o discurso de que, por exemplo, a trajetória dos fatos obedece a uma direção evolucionária da humanidade, como defendem os marxistas (GIDDENS, 1991: 55), ou para validar o discurso de que agora chegou o tempo em que se findam os relatos históricos, como dizem alguns teóricos pós-modernos. É mais correto, portanto, falarmos em perda da historicidade do que profetizarmos o fim da história. $\bigcirc$ pragmatismo capitalista, a valorização muitas vezes exagerada da novidade são 
fatores que estariam por trás dessa perda da historicidade, fenômeno que Jameson classificou como o "sintoma singularmente privilegiado" da contemporaneidade (1996: 18). Para o pensador norte-americano, a teoria sobre a pós-modernidade é uma tentativa de recuperação histórica da geração que teria esquecido como pensar historicamente. Tentativa heróica, diga-se, dadas às circunstâncias nebulosas de nossa época:

A teoria do pós-modernismo é uma dessas tentativas [desesperadas de recuperação];
o esforço de medir a temperatura de uma época sem os instrumentos e em uma
situação em que nem mesmo estamos certos de que ainda exista algo com a
coerência de uma "época", ou Zeitgeist, ou "sistema" ou "situação coerente". A teoria
do pós-modernismo é, então, dialética, pelo menos na medida em que tem a
sagacidade de usar essa incerteza como sua primeira pista e agarrar-se a esse fio de
Ariadne em seu caminho através de algo que talvez não se revele, no fim das contas,
um labirinto, mas um gulag, ou talvez um shopping center. (JAMESON, 1996: 14-15)

Tomemos então o fio de Ariadne para voltarmos ao início da teoria sobre a pós-modernidade: o anúncio do fim dos grandes relatos que no passado organizavam nossa visão de mundo.

\section{O fim das grandes narrativas}

A obra histórica de Lyotard nasceu da encomenda feita pelo conselho universitário do Québec, no Canadá, que solicitou ao francês a análise sobre o estado do saber nas sociedades contemporâneas desenvolvidas. $\bigcirc$ livro, por isso, aborda os desdobramentos da pós-modernidade na produção científica e não nas manifestações culturais. Em $A$ condição pós-moderna, Lyotard nos diz que na pós-modernidade perdemos a baliza dos grandes relatos ordenadores do mundo. No seu entender, havia duas grandes metanarrativas que conduziam a produção científica da modernidade. A primeira nascera com a Revolução Francesa e tinha como meta a busca pela libertação da humanidade através do avanço do conhecimento. Já a segunda vinha do idealismo alemão, marcado pela fundação da Universidade de Berlim (no primeiro decênio do século 19), e tinha na busca pela verdade o motor do progresso científico. A sociedade pós-moderna, porém, teria deixado de acreditar em tais metanarrativas, de resto, teria perdido toda motivação ideológica ou espiritual para se manter em andamento. Seu motor passou a ser a performance, a funcionalidade, o pragmatismo capitalista. Nas narrativas do passado, tínhamos sempre valores a nos servir de arrimo. Mas a busca pelo "bom", pelo "justo" e pelo "verdadeiro", que desde a Grécia antiga nos entretinha e nos movia, agora morre ao se chocar com a questão básica do pragmatismo pós-moderno: para que isso me serve, afinal? Dez anos antes da queda do Muro de Berlim, escrevia Lyotard:

O grande relato perdeu sua credibilidade, seja qual for o modo de unificação que lhe é conferido [...]

Pode-se ver neste declínio dos relatos um efeito do desenvolvimento das técnicas e das tecnologias a partir da Segunda Guerra Mundial, que deslocou a ênfase sobre os meios da ação de preferência à ênfase sobre os seus fins; ou então o redesdobramento do capitalismo liberal avançado após seu recuo, sob a proteção do keynesianismo durante os anos 1930-60, renovação que eliminou a alternativa comunista e que valorizou a fruição individual dos bens e dos serviços. [...] O impacto que, por um lado, a retomada e a prosperidade capitalista e, por outro lado, o avanço desconcertante das técnicas podem ter sobre o estatuto do saber é certamente compreensível. (2004: 69) 
O fim da alternativa comunista, marcado emblematicamente pela queda do Muro, foi duro golpe na já combalida organização simbólica do mundo. As primeiras rachaduras, porém, começaram a surgir muito antes, o que nos abre a possibilidade de pensar a pós-modernidade como a intensificação ou ápice do processo iniciado há muito. Em 1917, Freud identificava o que ele chamou de "três severos golpes no narcisismo universal do homem" (1969: 174-178). O primeiro deles foi o golpe cosmológico causado no século 16 por Nicolau Copérnico, que retirou a Terra do centro do universo. Em seguida, sofremos o golpe biológico, aquele causado pela obra de Charles Darwin, que, no século seguinte, ousou postular a ascendência animal da espécie humana. Por fim, Freud creditou à própria psicanálise o terceiro grande golpe em nosso narcisismo, o golpe psicológico, uma vez que a descoberta dos processos mentais inconscientes acabou por colocar em cheque a soberania de nossas decisões, mostrando que o ego daí em diante não mais poderia ser "o senhor da sua própria casa". Um século depois, Stuart Hall faria algo parecido ao identificar os cinco "descentramentos" (2004: 34-46) do sujeito pós-moderno, reconhecendo o trabalho de Freud como um deles, incluindo outros quatro: o marxismo, que colocou as relações econômicas e não o homem no centro da dinâmica social, o trabalho de Ferdinand de Saussure, que vê a língua como sistema preexistente ao indivíduo, as contribuições de Foucault sobre a presença camuflada de um feroz poder disciplinar a regrar nossas vidas e, por fim, o impacto do feminismo, que lançou novo olhar sobre as instituições e os comportamentos humanos.

Golpes no narcisismo e descentramentos sucessivos do sujeito foram minando as certezas, eliminando a pretensão de controle do mundo, invalidando antigos discursos, destruindo modelos de organização de realidade erigidos há séculos. Claro que novas propostas de leitura do mundo continuam a surgir, mas, como afirma Pierre Lévy, vivemos hoje a "indeterminação de um sentido global qualquer" (2000: 15), outro modo de se referir ao fim das grandes narrativas de Lyotard. $\bigcirc$ que não nos faltam hoje são profetas a explicar como o mundo funciona, a dizer para onde ele deve seguir, só que agora cada qual fala a sua platéia modesta e particular, fala às paredes talvez. Temos fragmentos apenas, sentimos falta da unidade, ou, como quer Slavoj Zizek, amargamos a "inexistência de um Acontecimento" (2003: 21), este, com A maiúsculo, que assim viria (porém não veio) com seu efeito organizador global -e aqui novamente temos eco da nossa percepção do fim da história. Vivemos o sentimento de falência das instituições, assistimos ao esfacelamento das moradas ideológicas que nos abrigavam. O homem pós-moderno não tem mais o sólido arcabouço compartilhado de valores que orientava seus antepassados. Agora tudo está em risco e tudo é questionado. Entregue à própria sorte, a humanidade desconfia dos valores que um dia Ihe foram sagrados. Narrativas de ressonância global não há mais que nos conduzam, vivemos o imediatismo pragmático do mercado, do consumo. Estreitam-se os caminhos que nos permitiriam entabular e levar adiante projetos de vida de verdadeiro significado, essa necessidade básica pelo heroísmo que, no entendimento do psicólogo e pensador norte-americano Ernest Becker, se esconde em cada ser humano. Partindo das sociedades primitivas que mais fartamente ofereciam caminhos de realização do heroísmo individual, chegamos à contemporaneidade, este tempo em que qualquer tentativa mais séria de projeto heróico pode ser de pronto desacreditada, quando não ridicularizada, então só nos resta consumir um pouco mais. Escreve Becker: 
Na nossa civilização, em todo caso, em especial na era moderna [contemporânea], o heróico parece grande demais para nós, ou nós parecemos pequenos demais para ele. Diga a um jovem que ele tem o direito de ser herói, e ele ficará ruborizado. Disfarçamos a nossa luta acumulando números numa conta bancária para refletir em particular o nosso senso de valor heróico. Ou tendo apenas uma casa um pouco melhor no bairro, um carro maior, filhos mais inteligentes. Mas por baixo disso pulsa a ânsia pela excepcionalidade cósmica, por mais que a disfarcemos em empreendimentos de menor amplitude. (1995: 18)

Antes tínhamos mitos, discursos, avistávamos as fronteiras de um mundo limitado pela natureza; agora nem natureza temos mais. Todas as feras foram domadas, todos os dragões foram mortos. Na modernidade, ainda havia "zonas residuais" de domínio da natureza, para novamente citarmos Jameson. Ainda sentíamos a presença do velho, do arcaico, do mitológico. Os modernos criam na razão, no poder da ciência em jogar luz nos cantos escuros do planeta, na capacidade do homem de afugentar os últimos fantasmas da mistificação. Agora que todos os cantos estão iluminados e todos os vultos foram banidos nos sobra o quê? Para Jameson, "o pós-modernismo é o que se tem quando o processo de modernização está completo e a natureza se foi para sempre" (1996: 13). No lugar deixado vago, temos a própria cultura, o universo simbólico, que acabou por se tornar nossa segunda natureza. Em sua análise marxista, Jameson sugere que a cultura não é mais o instrumento ideológico do capitalismo usado para promover a venda de mercadorias. Por outra, a cultura teria se tornado a mercadoria primordial do capitalismo, já que "o pósmodernismo é o consumo da própria produção de mercadorias como processo" (1996: 14). A pós-modernidade teria promovido a indistinção entre economia e produção cultural, entre natureza e cultura. Se o discurso tem seu fim em si mesmo e se serve apenas para manter a máquina em movimento, não temos mais razões exteriores a nos guiar. Nosso mundo se mostra o caótico conjunto de vozes, de narrativas múltiplas sem a presença de um fator que nos possa indicar o norte. Não temos mais aquele que por tanto tempo colocou prumo e baliza em nosso mundo, pois Deus está morto desde que Zaratustra nos anunciou seu passamento. Começamos então a imaginar que, como propunha o personagem de Dostoiévski, se Deus não existe, tudo é permitido. "O que se vê, então?", pergunta o filósofo Louis Kodo; ele próprio responde:

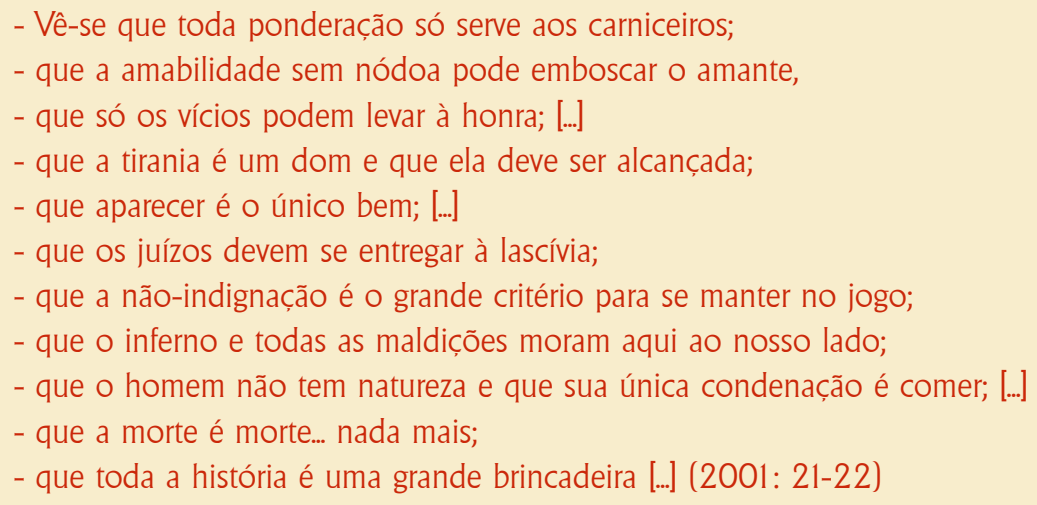

A pós-modernidade é a era da perversão de todas as coisas, da destruição de todos os ídolos, de inversão de todos os valores. Arcamos com o desconforto dessa orgia destruidora; por outro lado, abandonamos de vez a velha casca e nos abrimos para a possibilidade do vôo da renovação, soltando as seculares amarras simbólicas que nos detinham. Ao pensarmos na condição pós-moderna pelo viés otimista, perceberemos que a iconoclastia desvairada permitiu que puséssemos terminar de pôr abaixo séculos de aceitação cega de normas religiosas e culturais. 
Das regras da moral cristã que nos oprimiam desde a Idade Média à pretensão dos modernistas, tudo foi demolido pelas incertezas da contemporaneidade. $\bigcirc$ fim das certezas nos ameaça, mas nos traz possibilidades de inédita renovação. Muito mais do que simples apêndice da modernidade, a era em que vivemos poderá ser entendida no futuro como momento-chave de evolução para nossa cultura, por ter sido o ponto culminante do processo de destruição das velhas certezas, o ponto de abertura de novos caminhos.

De todo modo, o processo por enquanto não é fácil para o homem contemporâneo, que ao nível da rua, do chão duro de concreto, encara a realidade da vida em megalópoles que se movem aparentemente sem razão. $\bigcirc$ fim dos grandes relatos, a subjugação da natureza e a morte de Deus nos deram inédita liberdade individual, mas cobraram o preço da intranqüilidade e da incerteza. Podemos agora ir a qualquer lugar, mas não sabemos bem aonde ir nem qual o caminho certo a se tomar afinal. Tornamo-nos, na avaliação do psicanalista Jurandir Freire Costa, "uma multidão anônima, sem rosto, raízes ou futuro comum. E, se tudo é provisório, se tudo foi despojado da dignidade que nos fazia querer agir corretamente, quem ou o que pode apreciar o 'caráter moral' de quem quer que seja?" (1999) Com o fim das certezas, ninguém mais nos dirige. Vemos que "o palco foi tomado pela platéia" (KODO, 2001: 11) e ninguém mais sabe como terminará o espetáculo. Até a possibilidade de heroísmo furioso trazido pela cruzada iconoclasta acabou por se esgotar. $\bigcirc$ gozo enfurecido de quem derruba um antigo muro a marretadas, a excitação advinda após a platéia ter tomado o palco, todas essas coisas foram perdendo força e sentido com o avançar dos anos nesta era pós-moderna, colocando em cheque outra vez as alternativas de heroísmo neste mundo provisório. Agora o que nos resta? Há alguma coisa além do entulho e do tédio que nos assalta pela "banalização do gesto pretensamente extremo" (ZIZEK, 2004: 42)? Unimo-nos para juntos ridicularizarmos e afinal terminarmos de derrubar os altares sagrados construídos por nossos antepassados. Agora que o trabalho está feito e só nos resta o entulho poeirento pelo chão, não sabemos o que fazer a seguir, não há mais grandes projetos em comum. $\bigcirc$ homem contemporâneo perdeu a bússola e se sente só.

Mas a pós-modernidade, sempre contraditória, também vê possibilidades de integração nesse cenário de fragmentação aparentemente irreversível. Como reação oposta e complementar ao estilhaçamento das grandes narrativas, presenciamos ousadas tentativas de unificação, talvez mais ambiciosas do que antes se mostravam. Um exemplo no campo da ciência é a chamada teoria do campo unificado, a meta perseguida por alguns cientistas contemporâneos para chegar ao princípio geral que explicaria forças gravitacionais, eletromagnéticas e nucleares, lei que unificaria todas as teorias da física. No terreno social, o ocidente já há algum tempo -e cada vez mais- volta seus olhos para a cultura e a espiritualidade orientais, tentando substituir o conceito do defunto Deus patriarcal por uma abordagem "holística", essa palavra que de tão popular nos nossos dias tornou-se inteiramente desgastada. Agora, mais do que nunca, ganham força movimentos ecologistas que pregam o relacionamento simbiótico, mais do que isso, respeitoso entre a humanidade e as outras espécies do planeta. Em vez de máquinas fumegantes e desbravadoras do ideal modernista, temos o fortalecimento do ideal de desenvolvimento sustentável, em alguns casos, o retorno a modelos econômicos pré-modernos como no caso dos alimentos orgânicos. A globalização, reforçada pela ampliação do uso da internet, enfraquece as fronteiras e as formas nacionais de identidade cultural (HALL, 2004: 73), por outro lado começa a construir o esboço de uma consciência planetária. 
O importante, em suma, é notar que a derrocada das metanarrativas que organizavam boa parte do mundo, essa perda do sentido global, permitiu que inúmeros outros discursos surgissem e se desenvolvessem. Grosso modo, podemos dizer que é possível se encontrar de tudo na selva pós-moderna, mesmo o retorno de "velhos avatares" (JAMESON, 1996: 16) do modernismo, convivendo pacificamente com os arautos do fim do mundo. A pós-modernidade é aquele grande shopping center de relatos, discursos, ideologias e modos de viver que fervilham nas megalópoles sujas do nosso planeta. Somos livres para narrar nesta era de incertezas. Podemos tudo enquanto nada é para sempre.

\section{Real X Virtual}

Na pós-modernidade, mais do que nunca, é difícil pensar na existência do real. $O$ ser humano vive mergulhado em signos, pois ao longo dos séculos foi ampliando enormemente o nível de abstração simbólica com o qual lida com o mundo. Nunca antes teve sua realidade tão mediada como agora, na era pósmoderna. Estamos criando a terceira geração nascida em frente aos aparelhos de televisão, entramos na segunda década de uso da internet comercial. O mundo lá fora (se ainda podemos pensar em algo assim) nos chega sempre mediado pelas janelas eletrônicas onde nos debruçamos. Para Jean Baudrillard, testemunhamos a época em que estamos tão afastados do real que não mais exigimos que os signos garantam qualquer contato com as coisas que representam, vivemos o tempo em que não se pede qualquer fundamentação do signo na realidade. Para todos os efeitos, não existe mais uma realidade dura com a qual possamos (queiramos) lidar, pois estamos planando a quilômetros de distância acima do nível zero do real. Vivemos a era do "simulacro puro" (BAUDRILLARD, 1983: 12), vivemos o que Baudrillard chama de hiper-realidade, a realidade criada por símbolos, signos, palavras e imagens, que para nós têm a missão de serem mais reais do que real. Para o teórico francês, esse processo incessante e complexo de simulação da realidade traz novamente a opacidade das concepções de valor, pois forças antes claramente antagônicas se confundem e se complementam no jogo das posições simbólicas. Se olharmos, por exemplo, para o campo da política, os conceitos de direita e esquerda atualmente não terão mais o significado que tinham no passado, poderão perfeitamente trocar de posição dependendo das circunstâncias na batalha de simulação política. Os atentados de 11 de Setembro, para pegarmos um segundo exemplo, foram planejados de modo que houvesse intervalo entre o primeiro e o segundo impactos para que a televisão pudesse mostrar ao vivo a desfecho da tragédia. Até hoje, há gente a sugerir a hipótese de envolvimento (ou no mínimo conivência) do serviço secreto norte-americano. As cenas horripilantes do atentado cinematográfico podem servir a terroristas desejosos em atingir a imagem do império norte-americano, mas podem também ser úteis ao governo dos EUA em seu desejo de demonizar o mundo árabe. Tudo é signo, tudo é imagem. Esta é a era do simulacro pós-moderno de Baudrillard.

Como é regra neste tempo de exceções, não há consenso sobre a existência dessa "lamentável queda em direção aos simulacros hiper-reais" (HUTCHEON, 1991: 16). Hutcheon diz que "apenas descartar a realidade, conforme faz Baudrillard, não equivale a provar que ela foi degenerada transformando-se em hiper-realidade". Em vez disso, a pós-modernidade "sugere 
que tudo aquilo que sempre tivemos para trabalhar é um sistema de signos, e que chamar a atenção para isso não é negar o real, mas lembrar que apenas atribuímos sentido ao real dentro desses sistemas de significação" (1991: 288). Isto é, a lassidão dos limites entre realidade e linguagem -cada vez mais flagrantenão seria algo novo em si; a novidade estaria no fato de que agora a percebemos claramente: real e virtual se fundem, não há como separá-los.

$\mathrm{Na}$ contemporaneidade, as certezas da era moderna foram substituídas pelo exuberante e irreprimível jogo simbólico da pós-modernidade. Com o desenvolvimento da internet, as possibilidades desse jogo alcançaram novo patamar de sofisticação, uma vez que a rede mundial de computadores descentraliza a produção e a veiculação de conteúdos. Milhões de pessoas, em diferentes partes do globo, consomem, reciclam e produzem discursos, opiniões, boatos, ficções, imagens e vídeos por trás das máscaras cibernéticas com as quais navegam na internet. A democratização da fábrica de simulacros -democratização em termos, não nos esqueçamos da parte do mundo que ainda nem goza dos avanços da era moderna- começou ainda antes da internet com a popularização dos primeiros computadores pessoais. Há mais de duas décadas, usuários caseiros começaram a produzir a baixos custos toda sorte de produtos culturais: texto (em panfletos, jornais, revistas e hipertexto), som (em CDs ou formatos digitais nãofísicos) e imagem (em DVDs ou on-line sob demanda), tanto na captura quanto na edição dessas informações -sempre lidas, relidas, modificadas e retransmitidas de maneira caótica e interminável. Assim não podemos absorver hoje um corpo informacional que não seja necessariamente ínfimo, relativo e particularíssimo. Navegamos por esse mar infinito de informações que são absorvidas e ressignificadas por cada um dos cérebros humanos hoje conectados em rede. A esse respeito, escreve Pierre Lévy:

\footnotetext{
As telecomunicações geram esse novo dilúvio [dilúvio informacional, em oposição ao bíblico] por conta da natureza exponencial, explosiva e caótica de seu crescimento. A quantidade bruta de dados disponíveis se multiplica e se acelera. A densidade dos links entre as informaçōes aumenta vertiginosamente nos bancos de dados, nos hipertextos e nas redes. Os contatos transversais entre os indivíduos proliferam de forma anárquica. É o transbordamento caótico das informações, a inundação de dados, as águas tumultuosas e os turbilhões da comunicação, a cacofonia e o psitacismo ensurdecedor das mídias, a guerra das imagens, as propagandas e as contra-propagandas, a confusão dos espíritos.

[...] O segundo dilúvio não terá fim. Não há nenhum fundo sólido sob o oceano das informaçōes. Temos de ensinar nossos filhos a nadar, a flutuar, talvez a navegar. (2000: 13-15)
}

A analogia do ciberespaço com um oceano de fundo e horizontes inalcançáveis nos parece impossível de evitar. Desde o início, utilizar a rede era navegar. Netscape Navigator, o primeiro browser digno de nota, além do nome revelador trazia no logotipo o timão de um barco singrando o oceano da informação. Cada explorador da rede, em sua embarcação individual, bóia minúsculo sobre o estupendo mundo informacional, formando esse "fino enredamento dos humanos de todos os horizontes em um único e imenso tecido aberto e interativo" (LÉVY, 2000: 14). Os contatos transversais e caóticos que hoje unem os indivíduos -geograficamente distantes, ciberneticamente contíguosacabaram por realizar de uma vez por todas a vocação pós-moderna para a descrença a respeito de qualquer coisa que pudesse propor um sentido global. 
Hoje não há mais mensagens universais "totalizantes" (2000: 14), que possam apresentar em discurso sólido postulados sobre uma única realidade, pois temos a co-presença de infinitas mensagens. Os grandes relatos deram lugar à multiplicidade irrefreável de discursos, construindo a malha simbólica, os "rizomas do sentido" (2000: 249), como quer Lévy, cultivados, consumidos, ampliados e modificados simultaneamente por cada um dos exploradores ciberespaciais.

Dispomos hoje de mais uma centena de canais a cabo, consumimos conteúdo sob demanda e em "tempo real" distribuído em nossos celulares, divertimo-nos com videogames que emulam a realidade fantástica dos filmes hollywoodianos, navegamos pela infinidade de sites, depois baixamos toneladas de músicas da rede para nossos players de mp3 sem tocarmos em qualquer mídia física. Então trabalhamos de dez a doze horas por dia em frente a monitores de computador produzindo conteúdos informacionais também não-físicos para ao fim do dia "conversamos" com nossos amigos através de teclados e câmeras digitais. À noite, antes de desligarmos o sistema, fingimos ser real os dramas humanos que se desenrolam nos reality shows da televisão aberta. Agora boa parte de nossas experiências de vida se dá apenas dentro do jogo de simulações e nossa história pode ser lida como mais uma das "correntes turbilhonantes do novo dilúvio" (2000: 249). Vivemos o filme de nós mesmos, o videogame de nós mesmos, somos narrados em hipertextos acessáveis por links da "biblioteca de Babel" (2000: 16). O que pode ser considerado realmente real hoje em dia? Todas as idéias são igualmente válidas, porque igualmente relativas. Ecoando Baudrillard, Zizek escreve sobre o 11 de Setembro:

\footnotetext{
A Realidade Virtual simplesmente generaliza esse processo de oferecer um produto esvaziado de sua substância: oferece a própria realidade esvaziada de sua substância, do núcleo duro e resistente do Real -[...] a Realidade Virtual é sentida como a realidade sem o ser. Mas o que acontece no final desse processo de virtualização é que começamos a sentir a própria "realidade real" como uma entidade virtual. Para a grande maioria do público, as explosões do WTC aconteceram na tela dos televisores, e a imagem exaustivamente repetida das pessoas correndo aterrorizadas em direção às câmeras seguidas pela nuvem de poeira da torre derrubada foi enquadrada de forma a lembrar as tomadas espetaculares dos filmes de catástrofe, um efeito especial que superou todos os outros [...]. (2003: 25)
}

A "virtualização" da realidade, portanto, intensificou a carência de balizas sólidas experimentada pela pós-modernidade. Acabou por dar cabo das já moribundas narrativas modernas que anteriormente totalizavam nosso mundo. Nada mais é visto sem ressalvas como manifestação da "realidade real". Nunca foi tão difundida a idéia de que a realidade é fruto do discurso -ou do enquadramento das câmeras em dado momento. $\bigcirc$ ambiente virtual também ampliou a solidão do sujeito pós-moderno, descrente da possibilidade de encontrar porto seguro, navegando em seu bote ao sabor das correntes que encontra. Por fim, a tecnologia da informação levou ao extremo a já citada compressão espaço-tempo, a aceleração dos acontecimentos tanto em escala global quanto no dia-a-dia do sujeito pós-moderno. Bombardeado de informações que lhe chegam por diversos canais, o homem contemporâneo corre contra o tempo, sente-se premido pela urgência em realizar tarefas e coletar informações. Em seu videogame particular, desempenhando o papel que imagina ser o correto no reality show da vida, o homem contemporâneo está sempre com pressa, mesmo sem saber ao certo aonde vai. 
Condenado a ser livre, o sujeito pós-moderno vai solto pela vida para supostamente fazer o que bem entende. Os discursos foram relativizados, os valores foram pervertidos, Deus não existe mais. Agora não há mais virtude ou ideal a quem devamos prestar obediência, somos livres para pecar, ou melhor, não há mais pecado que possa ainda ser cometido. Os tabus foram derrubados, os fantasmas foram todos enxotados, cada qual pode fazer de sua vida o que dela quiser, pois o homem contemporâneo deve explicações a si mesmo e a mais ninguém. Vagando solitário por imensas megalópoles -algumas delas com duas dezenas de milhões de habitantes-, esse homem parece ter perdido qualquer noção de comunidade, de projeto comum. Com o fim das grandes narrativas, temos a "hiperindividualização" (PERES, 2004: 6) como marca de nosso tempo. Não há forças organizadoras exteriores ao indivíduo (Ibid.), apenas obstáculos a serem contornados para se lograr a realização de um projeto pessoal montado caoticamente com a ajuda de dicas pescadas em notas de jornal, livros de autoajuda, comerciais de televisão, conversas de botequim. $\bigcirc$ projeto heróico individual é algo em constante transformação, pois em primeiro lugar a identidade não viu meios de se solidificar. Hall avalia que não podemos mais falar em identidade, mas sim em "identificações" momentâneas e seriadas, rostos montados e remontados ao longo dos infinitos corredores do supermercado de referências culturais:

\begin{abstract}
Esse processo produz o sujeito pós-moderno, conceitualizado como não tendo uma identidade fixa, essencial ou permanente. A identidade torna-se uma "celebração móvel": formada e transformada continuamente em relação às formas pelas quais somos representados ou interpelados nos sistemas culturais que nos rodeiam. [...] O sujeito assume identidades diferentes em diferentes momentos, identidades que não são unificadas ao redor de um "eu" coerente. Dentro de nós há identidades contraditórias, empurrando em diferentes direçōes, de tal modo que nossas identificações estão sendo continuamente deslocadas. [...] na medida em que os sistemas de significação e representação cultural se multiplicam, somos confrontados por uma multiplicidade desconcertante e cambiante de identidades possíveis, com cada uma das quais poderíamos nos identificar - ao menos temporariamente. (2004: 12-13)
\end{abstract}

O processo assim descrito nos traz a impressão de que na pósmodernidade conquistamos liberdade individual sem limites, mas aqui temos outra das contradições de nosso tempo. Somos aparentemente livres no desenvolvimento dessa hiperindividualidade, mas como explica o psicanalista Contardo Calligaris, nossa autonomia individualista é na verdade "nossa forma paradoxal de obediência à cultura à qual pertencemos" (1994: 6). A história de que agora o homem é livre para buscar seu sucesso é na realidade contraditória. A moral e os ideais comuns foram engolidos pelo pragmatismo de nossos dias, mas é premente como nunca a exigência de que tudo e todos sirvam para alguma coisa, para que todos tenham sua função e sejam bem sucedidos de acordo com a objetividade funcional do mundo pós-moderno. Cada qual tem a chance de assumir o papel de sua preferência, mas não é livre para fracassar. $\bigcirc$ homem contemporâneo é obrigado a dar certo. Então vemos que a pós-modernidade, pródiga em incoerências, criou mais um de seus paradoxos: somos hiperindivíduos cheios de medo, frágeis, assombrados pelo temor de fracassar no jogo das identificações e das simulações contemporâneas. Para Lipovetsky, o grande problema de nossa sociedade é paradoxalmente a "fragilização dos indivíduos -suicídio, ansiedade, depressão, medo dos desastres ecológicos, medo dos pais, medo da AIDS, medo de envelhecer, medo do desemprego, do futuro[...] [criamos] uma sociedade que produz muita ansiedade e psicopatologias" 
(PERES, 2004: 6). Aparentemente livre, o homem pós-moderno não pode errar. Teve de abrir mão dos antigos pilares do mundo e agora vive a "bisonha e miserável rotina de acumular dinheiro compulsiva e indefinidamente, sem jamais perguntar por que e para que", pois "tanto faz o bem e o mal, o justo e o injusto, quando o que temos como guia é o bem-estar do corpo e das sensações" (COSTA: 1999, passim). Mas mesmo a propalada busca contemporânea pela fruição ilimitada dos desejos não é livre de contradição. Como ilustra Zizek, o hedonista pós-moderno procura excessos controlados, transgressões seguras:

O exemplo mais acabado disso é o chocolate laxante, comercializado nos Estados Unidos com a seguinte injunção paradoxal: "Está com prisão de ventre? Coma mais deste chocolate!" -isto é, coma mais exatamente daquilo que causa prisão de ventre. E não é uma comprovação às avessas da hegemonia desse ponto de vista o fato de que o consumo realmente imoderado (em todas as suas formas mais significativas: drogas, sexo, fumo...) seja visto hoje como o principal mal a ser combatido?

[...] O objetivo último aqui é, seguindo a linha do café descafeinado, inventar o "ópio sem ópio".

[...] A estrutura do "chocolate laxante", ou seja, de um produto que contém o agente de sua própria inibição, pode ser entrevista em todo o panorama ideológico atual. (2004: 14)

Zizek complementa seu raciocínio dizendo que "tudo é permitido ao 'último homem' hedonista dos tempos que correm: pode-se desfrutar de tudo, desde que as coisas sejam desprovidas de sua substância, daquilo que as torna perigosas" (Ibid.). Para obtermos felicidade e êxito, precisamos tomar cuidado com exageros, cuidar da saúde, evitar gorduras hidrogenadas e caminhar pelo menos meia hora por dia. Assim, atravessando tempos de liberdade que se supunha irrestrita, acabamos por experimentar vida bastante regrada. Antes o homem, ao contar com discursos exteriores que justificavam sua existência, era indulgente com seus pecadilhos e desvirtudes. Hoje há sinais de proibido fumar em todos os lugares e o executivo de sucesso também é maratonista e acorda todos os dias às cinco e meia da manhã para "malhar" na academia. Nunca a pecha de loser foi tão insultuosa. Quem seremos se ao menos uma vez na vida não realizarmos proeza realmente digna de nota, como a escalada ao Everest, a volta ao mundo num veleiro ou a estampa de nosso rosto na capa da Forbes? Lipovetsky se refere ao paradoxo fruição-austeridade ao rotular nossa sociedade de "esquizofrênica", assim chamada por manifestar ao mesmo tempo comportamentos opostos, de excesso e cautela. Usa também o termo "caos organizador" (e "desordem organizada") (PERES, 2004: 6) para nomear a convivência entre a extrapolação dos limites e as regras não escritas do viver corretamente:

A hipermodernidade é uma cultura paradoxal, que combina o excesso e a moderação. Excesso, porque a lógica hipermoderna não tem mais inimigos [...] Há um sentimento de excrescência de ultrapassagem dos limites, em que as coisas caminham cada vez mais rapidamente porque os limites da tradição -Estado, religião- se perderam.

Mas, ao mesmo tempo, a sociedade hipermoderna valoriza princípios como a saúde, a prevenção, o equilíbrio, o retorno da moral ou de religiões orientais. Logo, existem comportamentos inteiramente excessivos, como a pornografia, em que absolutamente tudo é permitido, embora ao mesmo tempo a vida sexual seja muito moderada [...] a população é basicamente conservadora em matéria sexual. (Ibid.: 6-7)

homem pós-moderno mantém sob controle sua fome ilimitada de prazer, auto-impõe-se limites, tem o cuidado de empurrar para a virtualidade aquilo que não acha prudente realizar no mundo real, vide a pornografia on-line. É por isso que Calligaris diz ser o "serial killer pop" o ideal dos nossos tempos, já que ele, 
o sociopata matador em série, não tem escrúpulos em arrancar o gozo que procura da vida sem se preocupar com o resto do mundo, realizando o projeto hedonista pós-moderno até suas últimas conseqüências (1999: 8). Mas o homem comum precisa correr. $\mathrm{O}$ sujeito pós-moderno corre contra o tempo, corre atrás de algo que não sabe o que é. Ele quer ter sucesso, quer gozar neste mundo de simulações e discursos provisórios. Quer tudo, pode tudo, mas sabe que não deve se descontrolar, afinal não é essa história que quer escrever sobre quem planeja ser. Ele já não é o mesmo da semana passada, tampouco o mundo o é. Tudo parece estar fora de controle, mas esse sujeito precisa ir em frente: ganhar mais, poder mais, saber mais. A cidade está lá fora e ele precisa fazer alguma coisa a respeito. $O$ homem contemporâneo está no topo do mundo e quer se lançar ao espaço infinito, mas está sozinho. À sua volta, vê a multidão de pessoas perdidas como ele, como ele correndo para qualquer lugar. Esse hiperindivíduo acha que alguma coisa está para acontecer, quer muito que algo aconteça, só não sabe bem o quê. Vive na carne e na mente as contradições profundas desta era conturbada, sente a turbulência do tempo de incertezas. Vive a beleza e a confusão da época em tudo é questionado, mas em que quase nada deixa de merecer um segundo de atenção. Milhões e milhões de pessoas soltas pelo mundo, tentando encontrar por si mesmas as respostas para o futuro que as atropela.

\section{Referências Bibliográficas}

BARRENTO, João. A espiral vertiginosa. Lisboa: Cotovia, 2001.

BAUDRILLARD, Jean. Simulations. New York: Semiotext(e), 1983.

BECKER, Ernest. A negação da morte. Rio de Janeiro: Record, 1995.

CALLIGARIS, Contardo. Com quanta culpa se faz a modernidade. Folha de S.Paulo. 19.06.1994, Mais!, p. 6.

Serial killer: um ideal para os nossos tempos. Folha de S.Paulo. 14.10.1999, Ilustrada, p. 8.

CONNOR, Steven. Cultura pós-moderna: introdução às teorias do contemporâneo. São Paulo: Loyola, 1992.

COSTA, Jurandir Freire. Descaminhos do caráter. Folha de S.Paulo. 25.07.1999, Mais!, p. 5.

FREUD, Sigmund. Uma dificuldade no caminho da psicanálise. In: Obras completas. Volume XVII, p. 171-179. Rio de Janeiro: Imago, 1969.

GIDDENS, Anthony. As conseqüências da modernidade. São Paulo, Fundação Editora da Unesp (FEU), 1991.

HALL, Stuart. A identidade cultural na pós-modernidade. Rio de Janeiro: DP\&A Editora, 2004.

HASSAN, Ihab. The dismemberment of Orpheus: toward a postmodern literature. Madison: University of Wisconsin Press, 1982.

HUTCHEON, Linda. Poética do pós-modernismo. Rio de Janeiro: Imago, 1991.

JAMESON, Fredric. Pós-modernismo: a lógica cultural do capitalismo tardio. São Paulo: Ática, 1996. 
KODO, Louis L. Blefe: o gozo pós-moderno. São Paulo: Zouk, 2001

LÉVY, Pierre. Cibercultura. São Paulo: Editora 34, 2000.

LYOTARD, Jean-François. A condição pós-moderna. Rio de Janeiro: José Olympio, 2004.

MORLEY, David; CHEN, Kuan-Hsing. On postmodernism and articulation: an interview with Stuart Hall. In: Critical dialogues in cultural studies. London: Routledge, 1996.

NEWMAN, Charles. The post-modern aura: the act of fiction in a age of inflation. Evanston: Northwestern University Press, 1985.

PERES, Marcos Flamínio. O caos organizador. Folha de S.Paulo. 14.03.2004, Mais!, p. 4-7.

PROENÇA FILHO, Domício. Pós-modernismo e literatura. São Paulo: Ática, 1988.

ZIZEK, Slavoj. A paixão na era da crença descafeinada. Folha de S.Paulo. 14.03.2004, Mais!, p. 13-15. 2003.

Bem-vindo ao deserto do Real!! São Paulo, Boitempo Editorial, 